EREM 74/1

Journal of Environmental Research Engineering and Management Vol. 74 / No. 1 / 2018 pp. $60-70$
Vegetation Dynamics of Algerian's Steppe Ecosystem.

A Case of the Region of Tiaret

Received 2018/02

Accepted after revision 2018/03

\title{
Vegetation Dynamics of Algerian's Steppe Ecosystem. A Case of the Region of Tiaret
}

\section{Bouacha Mohamed Islem, M'hamed Maatoug}

Laboratory of Agro Biotechnology and Nutrition in Semi-Arid Zones, Faculty of Natural Sciences and Life. Ibn-Khaldun University, Tiaret, Algeria

\section{Mykola Kharytonova}

State Agrarian-Economic University, Dnipro, Ukraine

\section{Corresponding author: kharytonov.m.m@dsau.dp.ua}

State Agrarian-Economic University, Dnipro, Ukraine

The Algerian steppe pastures cover an area of 20 million hectares. Their geographical location gives them a buffer zone between the north with a sub-humid climate and the great arid Sahara in the south. The steppe ecosystem is now facing a serious problem of degradation - desertification. The characterisation of steppe vegetation and its use as a biological indicator makes it possible to define the evolution of the steppe ecosystem and to identify the changes that have occurred. An approach based on the combination of various studied parameters by the establishment of a geographical system is adopted. A series of Landsat satellite images, covering the period 1987-2016, with seven images was used to produce land use maps. Data from salinity index SI and moisture index NDWI as well as climatic data were acquired from the Google earth engine platform. The results obtained demonstrate a variability of the spatio-temporal distribution of the steppe vegetation of the study area with a tendency to degradation. The canonical correspondence analysis reveals associations between the steppe vegetation cover and the precipitation and salinity parameters, demonstrating a strong sensitivity of steppe vegetation to external hazards.

Keywords: steppe, desertification, GIS and remote sensing, Tiaret, Algeria. 


\section{Introduction}

The steppe ecosystem covers an area of 20 million hectares of the central part of the Algerian territory. They play an important role as buffer zone to mitigate negative Sahara desert impact on regional weather condition (Khader et al., 2014). It has been demonstrated that rain-fed cultivated fields may generate large amounts of wind-blown sediment in different regions (Ansmann et al., 2003; Birmili et al., 2008). In case of conversion of natural vegetated areas to cropland, the natural, mixed annual/perennial vegetation is replaced by purely annual vegetation, which ensures an effective soil cover for only a fraction of the year (Houyou et al., 2016). In socio-economic terms, where the steppe is a pastoral region, livestock farming is indeed the agricultural practice of nomads, local and indigenous population of the steppe.

The steppe faces a real problem of degradation caused by desertification. This phenomenon, which affects various ecosystems around the globe, represents the major threat to the sustainability of the natural biological resources of the steppe ecosystem (Aidoud et al., 2006). The causes of desertification, mentioned in several scientific works (Slimani and Aidoud, 2004; Hillel and Rozeinsweig, 2002; Nahal, 2004), are mainly anthropogenic (overgrazing, land clearing, irrigation with salt water) combined with ecological conditions of the environment (long drought, low rainfall, poor skeletal soils).

The consequences of desertification can be irreversible (loss of soil productivity, disappearance of local species). The steppe vegetation cover is an important biological indicator of the ecological state of the ecosystem. The characterisation of steppe vegetation is an alternative analysis that can determine the extent of degradation (Jauffret and Lavorel, 2003). It is knowledge of the ecological status of vegetation and the pressures it faces. It is necessary to identify the evolution of steppe rangelands in the Tiaret region through the analysis of vegetation dynamics. The principle of the study is to compare the land use maps made at different dates during the period from 1987 to 2016, with an interval of 4 years between each acquired scene. It allows comparing the spatial distribution of steppe vegetation and the factors influencing the evolution of the vegetation cover. A series of satellite images of the Landsat sensors was used, the Google earth engine online platform was used to acquire an index time series calculated on satellite images, notably the moisture index (NDWI) and the salinity index (SI). It also allows access to climate data (precipitation and temperature) at a reduced spatial scale, which provides better knowledge of the evolution of the vegetation.

The objective of the study was to study the evolution of the steppe vegetation in the Tiaret region of western Algeria, by using remote sensing data.

\section{Material and methods}

The Tiaret region, located in the central-western part of Algeria, is an Agro-Sylvo pastoral region. It is undergoing major socio-economic changes, which have the effect of exacerbating the pressure on natural biological resources. The study area is located on the semi-arid bioclimatic stage with cool winter, with an average rainfall of $300 \mathrm{~mm}$, the average temperature $21^{\circ} \mathrm{C}$, reaching a maximum of $45^{\circ} \mathrm{C}$ during the summer period and $-2^{\circ} \mathrm{C}$ during the winter season. The steppe vegetation is characterised by formations of alfa (Stipa Tenacissima) in the northern part, plant formations based on Legeum Spartum. The soils of the region are limestone skeletal steppe soils, subjected to the action of wind erosion.

For an optimal analysis of the problematic approach, the adopted methodology was organised in two distinct phases: acquisition of data and acquisition of images. At the first step, a set of data was used, including satellite images of Landsat sensors, as well as descriptive data of the physical environment acquired through the Google earth engine online platform. At the second step, Landsat sensor images were used for acquisition of images.

Indeed, the images provided by Landsat cover large areas. The Landsat images used as well as the acquisition dates correspond to the observation period from 1987 to 2016. The images were acquired at the rate of one image every 4 years, taken during the month of June (Table 1). 
Fig. 1

Situation map of the study area

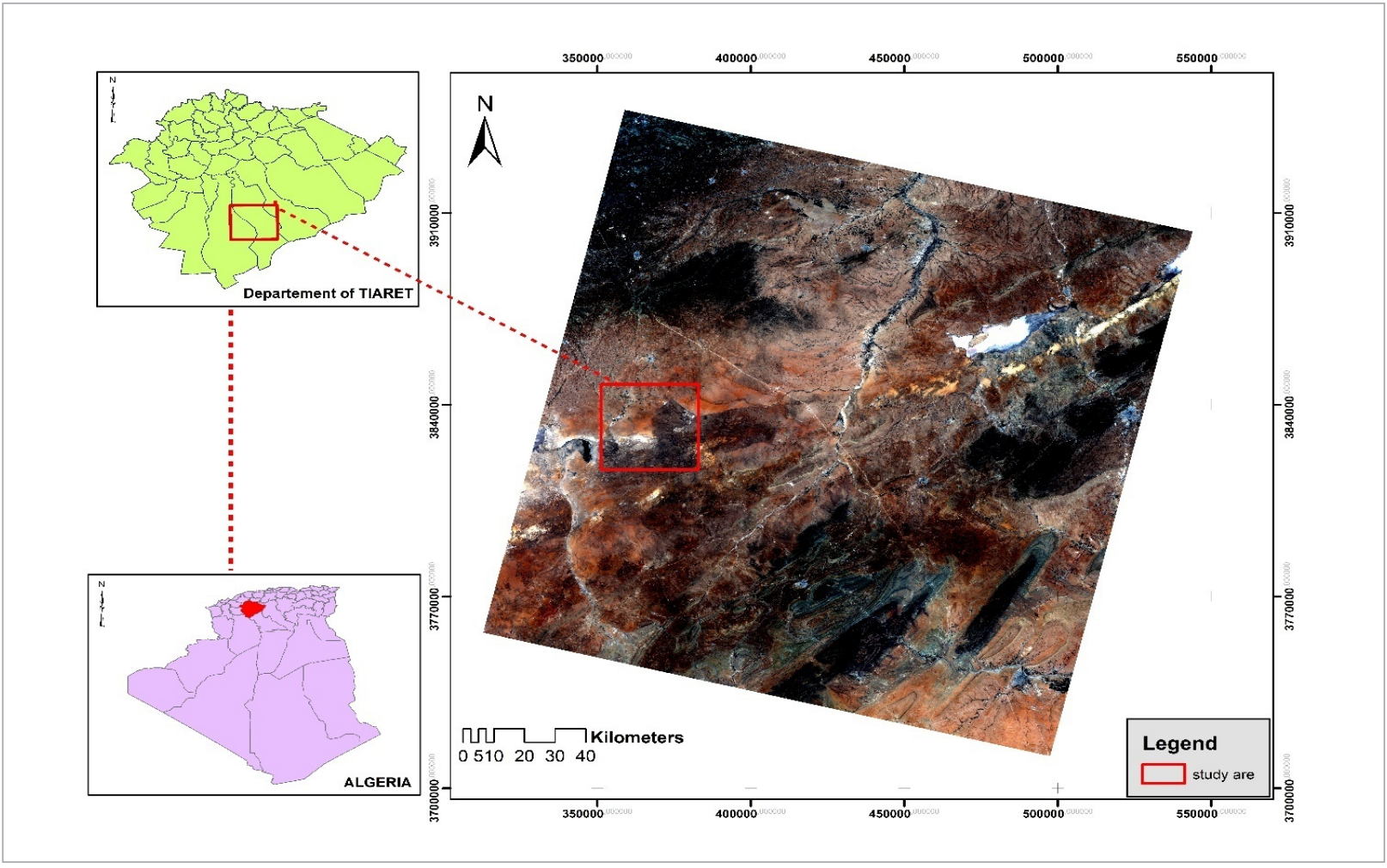

Table 1

Landsat scenes used and dates of acquisition

\begin{tabular}{c|c|c}
\hline Year & Sensor & Acquisition date \\
\hline 1 & 2 & 3 \\
\hline 1987 & Landsat TM & $07 / 07 / 1987$ \\
\hline 1995 & Landsat TM & $18 / 06 / 1995$ \\
\hline 1999 & Landsat TM & $18 / 09 / 1999$ \\
\hline 2003 & Landsat TM & $06 / 06 / 2003$ \\
\hline 2007 & Landsat ETM+ & $15 / 08 / 2007$ \\
\hline 2011 & Landsat TM & $14 / 06 / 2011$ \\
\hline 2016 & Landsat Oli & $08 / 06 / 2016$ \\
\hline
\end{tabular}

Precipitation maps were used, which were acquired through the Google earth engine online platform. The precipitation maps are CHIRPS the data product (Funk et al., 2015), which is available online for free during a long period of observation (from 1981). For this study, the salinity and moisture indices were used as land cover spectral reflectance parameters to see the correlation between edaphic and different vegetation characteristics (Elhag and Bahrawi 2017). In remote sensing, there are many indices that can be calculated directly on satellite images. In this study, the salinity index (SI) was retained (Douaoui et al., 2006). It was calculated by this formula: $\sqrt{ } G_{x} R$, where $G$ and $R$ are the visible bands of the Landsat images. Professor The data of the salinity index SI were acquired directly through Google earth engine at dates corresponding to the periods of observation. The NDWI moisture index is an indicator of soil moisture (Gao, 1996). This index was calculated for the study area. It was obtained via the platform Google earth engine. The choice of direct download of the indices was dictated by the speed and speed of acquisition. 
The Landsat satellite images used were the subject of a set of digital treatments prior to the completion of the land use maps (Table 2).

\section{Table 2}

RMSE table of the geometric correction

\begin{tabular}{c|c|c|c|c|c|c}
\hline Image & 1987 & 1995 & 1999 & 2003 & 2007 & 2011 \\
\hline 1 & 2 & 3 & 4 & 5 & 6 & 7 \\
\hline 2016 & 0.25 & 0.22 & 0.25 & 0.25 & 0.36 & 0.17 \\
\hline
\end{tabular}

Geometric correction was done by selecting reference points, called bitter points. Thirteen bitter points were used. The selection of ground control points in the steppe environment is difficult, They moved towards road intersections. The geometric correction is validated once the root means square error (RMSE) is less than or equal to 0.5 pixel. The images used in this study were acquired for radiometric correction via the website https://glovis.usgs.gov (2016). The images were provided at a level of pre-processing B1. The objective of this phase is to convert the NCs to the reflectance value. A classification supervised by the maximum likelihood method was adopted to produce the land use maps. Supervised classification was done through the selection of known land cover classes. Eleven classes were selected. The classification is validated after generation of a confusion matrix that allows assessing its relevance and reliability. We obtained a $97 \%$ confusion matrix with a kappa index of 0.97 . The analysis of the results of satellite image processing and the knowledge of the kinetics of the units land cover were involved in the creation of a geographic database, to assign each class of the physical parameters necessary for the analysis. The land use maps were obtained and generated in the vector format. Thereafter, a combination of maps via spatial queries (SQL) was performed for the creation of a database for each year of observation.

\section{Results and discussions}

The result of the supervised classification of the satellite images used leads to the realisation of a series of maps of land uses. The reading of the land cover maps suggests a region characterised by a chlorophyll element to non-chlorophyll element ratio, in favour of non-chlorophyll elements, with a dominance of the bare grounds. It was established that the study area had a problem of silting and a phenomenon of soil salinization. Steppe vegetation is mostly of medium density with a heterogeneous spatial distribution (Fig. 2).

The salinity index SI takes values ranging from - 1 where salinity is low to less than 1 indicating high salinity of soils. The data obtained indicated an average salinity during the period from 1995 to 2011 . The maximum value of SI was observed at the year 1987 $(\mathrm{SI}=0.35)$, indicating a high salinity of soils during this period. Moreover, a salinization trend was indicated between the year 2011 and 2016. The SI salinity index was 0.23 .

It is known that the NDWI moisture index indicates a severe drought if the value of the index is -1 and enough soil moisture if the NDWI is equal to 1 (Gao, 1996). The NDWI values obtained indicate that the study area is experiencing a greater or lesser degree of drought, given that it is in the bioclimatic stage. NDWI values range from a low of -0.38 in 2016 to a high of -0.34 in 1995, 2007 and 2011.

The CHIRPS climatic data indicate an irregular temporal distribution of accumulated rainfall, with a minimum of $195 \mathrm{~mm}$ recorded during the year 2007 and a maximum of $325 \mathrm{~mm}$ for the year 2011. The temperature values show a low temporal variability with a minimum of $14^{\circ} \mathrm{C}$ recorded during the year 1995 and a maximum of $18^{\circ} \mathrm{C}$ for the year 2011.

The detection of changes is an analytical problem, which is most often based on an image-to-image comparison or through a diachronic analysis. Seven satellite images were used. It seems incoherent to proceed to the detection of changes by conventional methods. In this sense, and for a better appreciation of the changes that occurred, we proceeded to a simple method, based on the estimation of the areas of each class of land occupation. The study of each class evolution during the period of observation allows to establish which changes in time are related each with other. 
Fig. 2

Land cover maps of the study area (1987-2016)

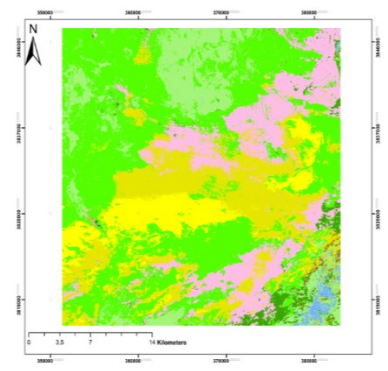

1987 1
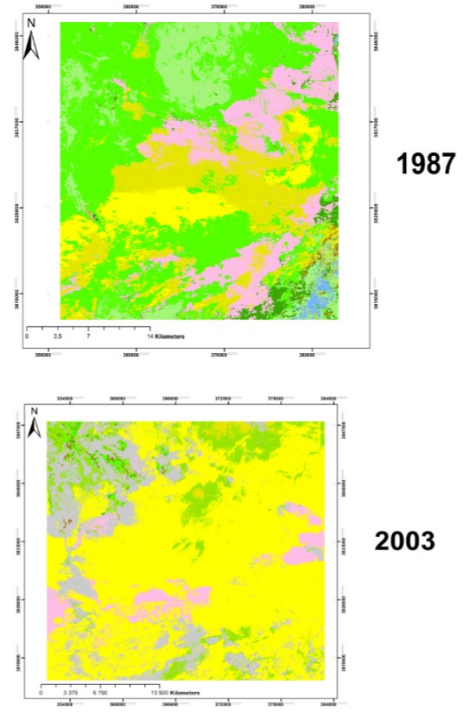

2003

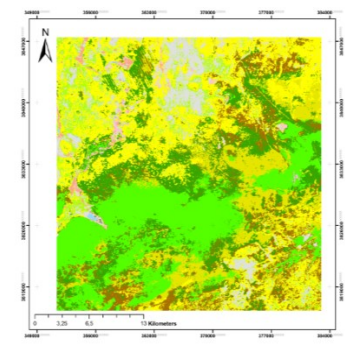

1995

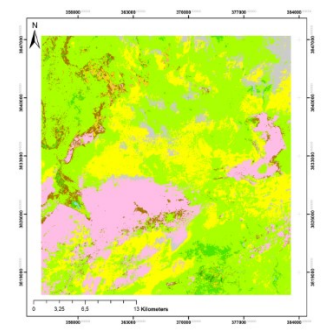

1999
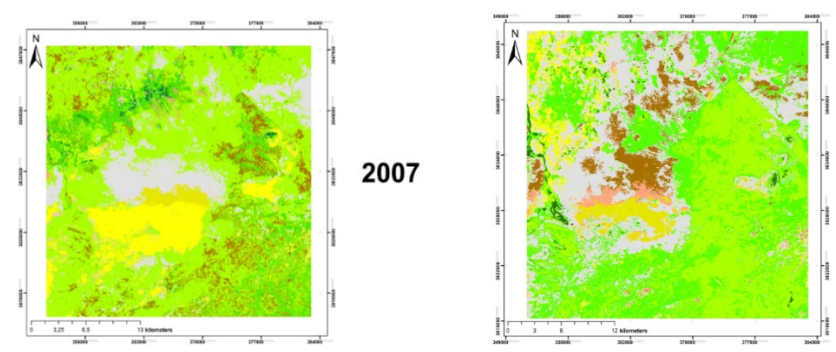

2011

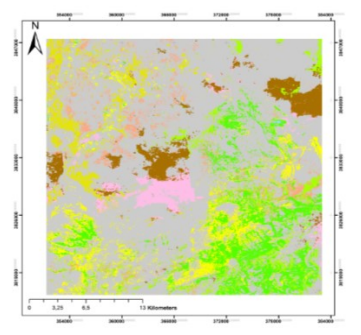

\begin{tabular}{|l|l|}
\hline CLASS & bare ground \\
\hline Rocky soil & bare limestone \\
Agriculture & Sparse vegetation \\
\hline Stable sand & Dense vegetation \\
\hline Unstable sand & Wetland \\
Forest vegetation & Average vegetation \\
\hline
\end{tabular}

The realisation of the land cover maps makes it possible to calculate the surface of each class. The land cover classes' evolutionary curve during the period 1987-2016 is shown in Fig. 3.

The evolution data presented in Fig. 3 shows an irregularity of the dynamics of the land use classes. Indeed, the bare soil class shows a tendency towards progression, indicating a situation of regressive evolution of the study area. Besides, the data obtained indicate a period of massive silting during the period from 1995 to 2007 with a maximum during the year 2003. Thus, we can talk about a consequent wind erosion process that occurred at the level of the region. The steppe vegetation shows an evolutionary irregularity, as well as a passivity compared with the other occupancy classes. It is a very high vulnerability to the hazards of the physical environment. It emerges that the steppe vegetation cover experienced four distinct evolutionary phases.

The average steppe vegetation recorded a growth rate of $2.53 \%$ for the year 1995 and $0.02 \%$ for the year 1999. Moreover, the class of sparse steppe vegetation showed a growth rate of $22.03 \%$ for the year 1995 and $105.35 \%$ for the year 1999. The growth rates calculated for the period from 1999 to 2003 showed a decline in the vegetation cover. Indeed, the class of dense steppe vegetation, which obviously showed a growth rate of $0.9 \%$ compared with 1987 , had a regressive evolution compared with the year 1999.

This finding of regressive evolution is more consolidated by the growth rate recorded for the average vegetation class, which recorded a rate of $-0.58 \%$ for 
Fig. 3

Evolutions of the land cover classes during the period 1987-2016

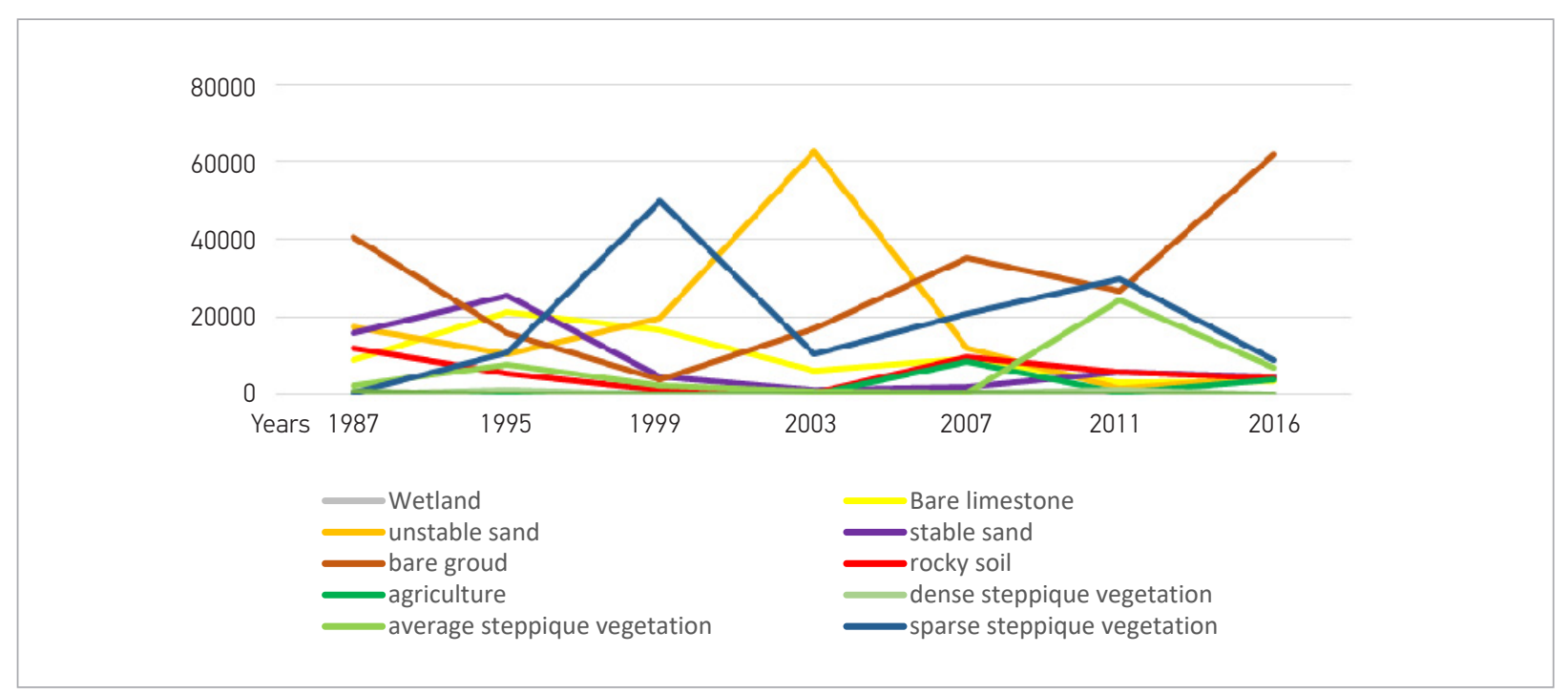

the year 2003 compared with 1987. The evolution of sparse vegetation with an increase rate of $21.03 \%$ is an indicator of the qualitative evolution of the vegetation cover demonstrating that the vegetation cover during the period 1999-2003 was regressively changing.

The analysis of growth rates of vegetation classes shows a progressive evolution. The dense steppe vegetation class recorded a growth rate of $2.7 \%$ for the year 2003 and $6.7 \%$ for the year 2007 with a maximum of $15.6 \%$ for the year 2011 . The average steppe vegetation showed a growth rate of $0.81 \%$ for the year 2007 and $9.56 \%$ for the year 2011 . The class of sparse steppe vegetation showed growth rates of $43.57 \%$ for the year 2007 and $62.7 \%$ for the year 2011. During this period, it emerges that the vegetation cover had a regressive evolutionary phase. The growth rates recorded for the three vegetation classes showed a rate of $-0.9 \%$ for the dense steppe vegetation class, $1.98 \%$ for the average vegetation class and a growth rate of $18.01 \%$ for the scattered steppe vegetation class. The type of evolution was identified in comparison with the rates obtained during the year 2011 . The results of the preliminary reading of the evolution of the vegetation classes showed an irregular evolution with phases of progressive and regressive evolution. The search for the reasons and causes that led to this conclusion implies an inter-class comparison between the different classes of land use. The confrontation of land cover classes for the period 1987-2016 makes it possible to elucidate the indicators responsible for the evolution of the vegetation.

The correlation matrix generated to identify the interclass relations makes it possible to define links between the classes of vegetation and the units of land cover. For the three classes, the correlation coefficient was calculated to identify the relation between the vegetation classes and other land use classes defined by a sample size $\mathrm{N}=11$ for each $\mathrm{r}$ value calculated.

The correlation coefficients obtained showed a moderate negative correlation between the dense vegetation class and the bare soil class with $r=-0.32$. The evolution of the dense vegetation class also moderately correlated with the evolution of the unstable sand class, with $r=-0.33$, and the stable sand class with $r=0.32$ by the correlation matrix indicates a strong negative correlation between wetland classes and forest formation and the dense vegetation class.

The average vegetation class showed moderate negative correlations with wetland classes $(r=-0.30)$, unstable sand $(r=-0.5)$, bare soil (limestone and minerals) with a coefficient $r=-0.31$ as well as with the agriculture class $(r=-0.27)$. 


\section{Table 3}

Correlation matrix between vegetation and land use classes

\begin{tabular}{c|c|c|c|c|c|c|c|c|c|c|c}
\hline & WL & BG & BL & US & SS & RS & AGR & FV & AV & SV & DV \\
\hline 1 & 2 & 3 & 4 & 5 & 6 & 7 & 8 & 9 & 10 & 11 & 12 \\
\hline DV & -0.4061 & -0.3223 & 0.1646 & -0.334 & 0.325 & 0.0618 & -0.0692 & -0.2097 & 0.7225 & 0.1539 & 1 \\
\hline AV & -0.3064 & 0.0431 & -0.314 & -0.506 & 0.078 & -0.0119 & -0.2769 & -0.3566 & 1 & 0.1979 & 0.72 \\
\hline SV & -0.2587 & -0.5848 & 0.2296 & -0.151 & -0.37 & -0.4377 & -0.0564 & -0.4572 & 0.1979 & 1 & 0.15
\end{tabular}

*DV, dense vegetation; AV, average vegetation; SV, sparse vegetation; BG, bare ground; BL, bare limestone; US, unstable sand; SS, stable sand; $\mathrm{RS}$, rocky soil; AGR, agriculture; FV, forest vegetation; WL, wetland.

The correlation matrix shows at least moderate negative correlation between the sparse vegetation class and wetland classes $(r=-0.25)$, bare soil $(r=-0.58)$, stable sand $(r=-0.37)$ and the forest formation class with a correlation coefficient $r=-0.45$. In addition, sparse steppe vegetation showed a moderate positive correlation with rocky terrain classes $(r=0.43)$ and the bare soil class (limestone and minerals) with $r=0.22$.

The analysis of the correlation matrix makes it possible to define the types of changes that occurred at the level of the study area.

The results obtained show that situations of regressive evolution occur in the regions. The progressive evolutions of the steppe vegetal cover take place in the regions where the sandy formations of the classes fixed sand and unstable sand regress. We are therefore talking about a biological recovery of the plant cover, where it is called pioneer communities. Steppe vegetation is also progressively evolving as wetland surfaces decrease so that steppe vegetation settles after surface drying of wetlands.

Regressive evolution situations occur mainly when the vegetation is medium and sparse. Indeed, the correlation matrix makes it possible to identify ecological regressions passing from average vegetation and scattered, with sandy formations, under the effect of wind erosion due to the proximity of the Algerian steppe with the great southern desert. Furthermore, the analysis of the interclass correlation allows unsealing another form of regression of the canopy, under the effect of the anthropic action, where the average and sparse vegetation classes show correlations with the agriculture class, demonstrating that the human action contributes to the degradation of the plant cover in the place.

The results obtained support the hypothesis of a degradation of the steppe ecosystem. Indeed, several authors evoke a tendency of steppe vegetation to degradation. Due to problems related to the action of wind erosion (Bensaid, 2006), the massive silting of the steppe ecosystem in Algeria is mainly due to the proximity of this ecosystem to the desert south.

Other parameters also play a role in the regressive evolutions of vegetation, notably the effect of human activity (Haddouche 2009), which is most often raised and which can explain the disappearance of the vegetal cover and its replacement by bare grounds, due to overgrazing (Maestre, 2004) and land clearing.

The results obtained show an irregularity in the evolution of vegetation cover in the study area. The result is a series of gradual and regressive developments that occurred during the period 1987-2016. However, a study of the dynamics of the vegetation should make it possible to identify the factors affecting these evolutions. Thus, there is an expressed need to answer the questions:

a why these types of evolutions took place?

b what factors have a direct effect on the vegetation cover in place?

This requires integrating in the investigation an analysis allowing integration of the parameters of the physical environment as variables explanatory of the dynamics.

In this sense, the data collected via Google earth engine, including salinity indices, soil moisture index 
and climate data, were compared with vegetation classes. The canonical correlation analysis (CCA) can provide answers to the questions raised. We used a CCA which allows finding out the degree of influence of each parameter on the steppe vegetation classes of the study area.

\section{Table 4}

Result of the permutation test

\begin{tabular}{l|c}
\hline Permutations & 500 \\
\hline Pseudo F & 0.3907 \\
\hline p-value & 0.9400 \\
\hline alpha & 0.0500 \\
\hline
\end{tabular}

The principle of the canonical analysis of correspondences is to emit two hypotheses opposite to each other:

Hypothesis HO: The vegetation class data are not linearly linked to the physical parameter data (SI, NDWI, $\mathrm{PP}$ and $\mathrm{T}^{\circ}$ ).

Hypothesis $\mathrm{H} 1$ : The vegetation class data are linearly related to the physical parameter data (SI, NDWI, PP and $\mathrm{T}^{\circ}$ ).
According to the ACC data obtained, the result showed that the average steppe vegetation was favoured by high rainfall values as well as low salinity values. We also found that sparse steppe vegetation was associated with conditions of the physical environment with average soil moisture at low rainfall levels. The graph could also be used to conclude that dense vegetation was associated with low values of explanatory variables. Soil salinity remains a major factor, the extent to which the three classes of vegetation are associated with low humidity.

The results obtained consistently demonstrated the effect of precipitation and salinity as preponderant factors having a direct effect on vegetation cover. As soil salinity is a direct factor in the desertification process (Nahal, 2004), it is an environmental variable that conditions the installation of the vegetation cover on saline soils, especially in steppe areas. The results obtained are consistent with the work of several researchers who argue that salinity is a limiting factor in the installation and sustainability of vegetation cover (Azabdaftari and Sunarb, 2016; Abbas et al., 2007; Allbed and Kumar, 2013).

The climatic factor, through its two variables (precipitation and temperature), positioned itself as a

Fig. 4

Canonical analysis of correlations linking vegetation, salinity, precipitation and soil moisture

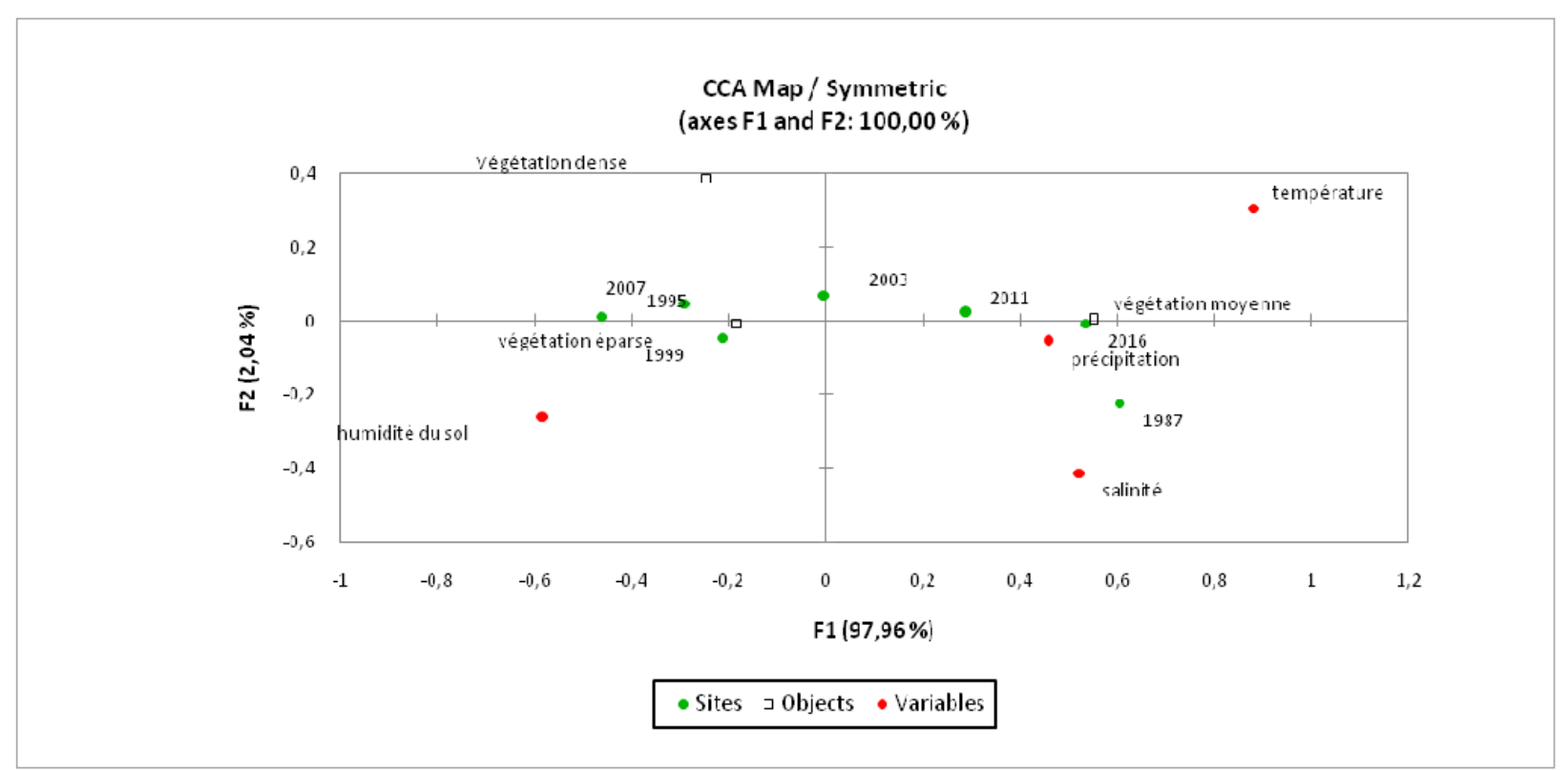


significant parameter having a direct impact on vegetation cover (Saidi and Gintzburger 2013).

The use of cumulative precipitation data allowed highlighting the relation with the vegetal cover in semi-arid environment. Nevertheless, the average temperature does not seem to be an explanatory variable as it has a low variability as well as the variable soil moisture.

\section{Conclusion}

The study of the dynamics of the steppe vegetation of the south of the Tiaret region allowed identifying the forms of ecological evolution during a period of observation spreading from 1987 to 2016. The results of land cover mapping at different dates led to the identification of land use units as well as knowledge of the dynamics of vegetation cover. The use of Google earth engine facilitates the acquisition of descriptive

\section{References}

Abbas, A., Khan S. (2007) Using remote sensing techniques for appraisal of irrigated soil salinity. International Congress on Modelling and Simulation of Australia and New Zealand Christchurch, New Zealand. : 2632-2638

Aïdoud A., Le Floc'h E., Noël Le Houérou H. (2006) The Arid steppes of North Africa, Sécheresse 17 (1-2) : 19-30 (in french).

Allbed, A., Kumar L. (2013) Soil salinity mapping and monitoring in arid and semi-arid regions using remote sensing technology: A review." Advances in Remote Sensing 2013 (2): 373-385. https://doi.org/10.4236/ars.2013.24040

Ansmann, A., B“osenberg, J., Chaikovsky, A., et al.: Longrange transport of Saharan dust to northern Europe: The 11-16 October 2001 outbreak observed with EARLINET, J. Geophys. Res., 108, D04783, doi:2003JD003757

Azabdaftari A., Sunarb F. (2016) Soil salinity mapping using mullti temporal Landsat data The International Archives of the Photogrammetry, Remote Sensing and Spatial Information Sciences, Volume XLI-B7, 2016 XXIII ISPRS Congress, 12-19 July 2016, Prague, Czech Republic data of terrestrial ecosystems. The use of products of SI salinity, NDWI soil moisture index and climate data made it possible to determine the influences of the mentioned parameters on the evolution of the steppe vegetation cover.

We also note a great irregularity of steppe vegetation dynamics, thus demonstrating the sensitivity of protecting the ecosystem against degradation processes. Moreover, the study demonstrated the sensitivity of the vegetation's steppe face and external disturbances, including climatic and edaphic. The soil salinity factor is presented as a real problem to be dealt with from a perspective of setting up strategies for the development of biological resources in the steppe environment.

The methodology adopted in this study suggests the possibility of integrating other explanatory variables, to involve other factors, including indicators of human action, likely to reinforce the methodological approach adopted.

Birmili W., Schepanski K., Ansmann A., Spindler G., Tegen1, Wehner B., Nowak A., Reimer E., Mattis I., M“uller K., Br“uggemann E., Gnauk T., Herrmann H., Wiedensohler A., Althausen D., Schladitz A., Tuch T., L“ oschau G. (2008). A case of extreme particulate matter concentrations over Central Europe caused by dust emitted over the southern Ukraine. Atmos. Chem. Phys., 8, 997-1016. https://doi.org/10.5194/acp-8997-2008

Douaoui, A.E.K., Nicolas H., Walter C. (2006) Detecting salinity hazards within a semi-arid context by means of combining soil and remote-sensing data." Geoderma 134 (1): 217-230. https://doi.org/10.1016/j.geoderma.2005.10.009

Elhag M., Bahrawi J.A. (2017) Soil salinity mapping and hydrological drought indices assessment in arid environments based on remote sensing techniques. Geosci. Instrum. Method. Data Syst., 6, 149-158, https://doi.org/10.5194/gi-6-1492017

Funk C., Peterson P., Landsfeld M., Pedreros D., Verdin J., Shraddhanand S., Husak G., Rowland J., Harrison L., Hoell A., Michaelsen J.. (2015) The climate hazards infrared pre- 
cipitation with stations - a new environmental record for monitoring extremes. Scientific Data 2, 150066. https://doi. org/10.1038/sdata.2015.66

Gao, B.C. (1996) NDWI: A normalized difference water index for remote sensing of vegetation liquid water from space. Remote Sensing of Environment 58: 257-266. https://doi. org/10.1016/S0034-4257(96)00067-3

Haddouche I. (2009) Remote sensing and the dynamics of the landscapes in the arid and semi-arid environments of Algeria: Case study in the Nâama region). PhD Thesis, Tlemcen University, Algeria.

Hillel D., Rosenzweig C. (2002) Desertification in relation to climatevariability and change. In: Sparks, D.I. (Ed.), Advances in Agronomy, vol. 77: 1-38. https://doi.org/10.1016/S00652113(02)77012-0

Houyou Z., Bielders C.L., Benhorma H.A., Dellal A., Boutem$\operatorname{djet} A$. (2016) Evidence of strong land degradation by wind erosion as a result of rainfed cropping in the algerian steppe: a case study at laghouat. Land Degrad. Develop. 27: 17881796.https://doi.org/10.1002/ldr.2295

Jauffret S., Lavorel S. (2003) Are plant functional types relevant to describe degradation in arid, southern Tunisian steppes? Journal of Vegetation Science 14: 399-408. https:// doi.org/10.1111/j.1654-1103.2003.tb02165.x

Khader, M., Mederbal K., Chouieb, M. (2014) Suivi de la dégradation de la végetation steppique a l'aide de la Télédétection: Cas des parcours steppiques région de Djelfa (Algérie). Courrier du Savoir 2014, 18:89-93 (in french).

Maestre F.T. (2004) On the importance of patch attributes, environmental factors and past human impacts as determinants of perennial plant species richness and diversity in Mediterranean semi-arid steppes. Divers. Distrib. 10 : 21-29. https://doi.org/10.1111/j.1472-4642.2004.00057.x

Nahal I. (2004) Desertification in the World: Causes, Dynamic consequences and Conflicts).' (Biologie, Ecologie et Agronomie Harmattan: Paris.) (in french).

Saïdi Slim S., Gintzburger G. (2013) A spatial desertification indicator for Mediterranean arid range lands: a case study in Algeria The Rangeland Journal, 2013, 35: 47-62

Slimani H, Aidoud A. (2004) Desertification in the Maghreb: A case study of an Algerian high-plain steppe. In: Marquina, A. (Ed.), Environmental Challenges in the Mediterranean 2000-2050. Kluwer Academic Publishers: 93-108. https:// doi.org/10.1007/978-94-007-0973-7_6

Les parcours steppiques algériens occupent une superficie de 20 millions d'hectares. Leur situation géographique, leur confère un rôle de zone tampon entre le nord à climat Subhumide, et le grand Sahara aride au Sud. L'écosystème steppique est aujourd'hui confronté à une grave problématique de dégradation : la désertification. La caractérisation de la végétation steppique et son utilisation comme indicateur biologique permet de définir l'évolution de l'écosystème steppique et d'identifier les changements intervenus. L'objectif de l'étude est d'étudier l'évolution de la végétation steppique de la région de TIARET, à travers l'utilisation des données de la télédétection. Une approche basée sur la combinaison de divers paramètres étudiés, par la mise en place d'un système géographique est adoptée. Une série d'images satellitaires LANDSAT, couvrant la période 1987-2016, avec de 7 images est utilisée pour la réalisation de cartes d'occupation des sols. Des données des indices de salinité IS et l'indice d'humidité NDWI, ainsi que climatiques sont acquises via la plateforme google earth engine. Les résultats obtenus démontrent une variabilité de la répartition spatio-temporelle de la végétation steppique de la région d'étude avec une tendance à la dégradation. L'analyse canonique des correspondances fait ressortir des associations entre le couvert végétal steppique et les paramètres de précipitations et de salinité démontrant une forte sensibilité de la végétation steppique aux aléas externes.

Mots clés : Steppe, désertification, SIG et télédétection, Tiaret 


\section{Alžyro stepių ekosistemos vegetacinè dinamika. Tiareto regione}

\section{Bouacha Mohamed Islem, M'hamed Maatoug}

Agrobiotechnologijos ir mitybos laboratorija, Gamtos mokslų fakultetas, Ibn-Khaldun universitetas, Tiaretas, Alžyras

\section{Mykola Kharytonov}

Valstybinis ekonomikos universitetas, Dnipro, Ukraina

Alžyro stepių ganyklos užima $20 \mathrm{mln}$. ha plotą. Ju geografinė padètis suteikia jiems buferinę zoną tarp šiaurès su subdrègnu klimatu ir sausra Sachara pietuose. Stepés ekosistema dabar susiduria su rimta degradacijos - dykumejimo problema. Stepès augmenijos apibūdinimas ir jo naudojimas kaip biologinis indikatorius leidžia apibrěžti stepinès ekosistemos evoliuciją ir nustatyti j̧vykusius pokyčius. Priimtas požiūris, pagrịstas j̇vairių tirtu parametrų deriniu įsteigiant geografinę sistemą. Žemès palydovu vaizdu serija, apimanti 1987-2016 m., su septyniais vaizdais buvo naudojama žemès naudojimo žemèlapių gamybai. Duomenys apie druskingumo indeksą SI ir dreggmès indeksą NDWI bei klimato duomenys buvo gauti iš "Google“ žemès varikliu platformos. Gauti rezultatai rodo, kad tyrimo zonos stepinès augalijos pasiskirstymo kintamumas yra linkęs i skilimą. Kanoninè korespondencijos analizè atskleidžia asociacijas tarp stepių augmenijos dangos ir kritulių bei druskingumo parametru, parodančiu stiprią stepių augalijos jautrumą išoriniams pavojams.

Raktiniai žodžiai: stepès, dykumejjimas, ekosistema, GIS ir nuotolinis zondavimas, Alžyras. 